J. Japan. Soc. Hort. Sci. 55(3) : 280-289. 1986.

\title{
Composition of Volatile Compounds of Apple Fruits in Relation to Cultivars ${ }^{1}$
}

\author{
Norio Kakiuchi and Sanae Moriguchi \\ Fruit Tree Research Station, Yatabe \\ Ibaraki 305 \\ Hiroyuki FuKudA \\ Fruit Tree Research Station, Morioka Branch, Shimokuriyagawa, \\ Morioka, Iwate 020-01 \\ Nobutomo Ichimura, Yutaka Kato and Yoshiaki Banba \\ Food Laboratory, Soda Aromatic Co., LTD, Noda, \\ Chiba $270-02$
}

\begin{abstract}
Summary
Experiments were carried out to analyse the cultivar differences in the composition and content of flavour compounds by applying the head space and high vacuum distillation methods.

1. Seventy to 80 compounds were detected in the gas chromatogram peaks of which 39 compounds were identified by gas chromatography-mass spectrometry.

2. The classes of the volatile compounds identified included 27 kinds of esters, 6 of alcohols, 2 of aldehydes and hydrocarbons, a phenol and an acid.

3. Esters were the most abundant flavour components detected when the head space method was applied, accounting for $80 \%$ or more of the total content of volatile compounds. And the total amounts of volatile compounds were highest in 'Hatsuaki' (1.889 ppm) followed in descending order by, 'Kogyoku' (1.531 ppm), 'Golden Delicious' (0.196 ppm), 'Mutsu' (0.187 ppm) and 'Fuji' (0.055 ppm).

4. The amount and composition of volatile compounds estimated by the high vacuum distillation method were nearly the same as those by the head space method. However, in the former method the class of alcohols was quantitatively the most abundant, the percentage of total volatile compounds ranging from $53.3 \%$ in 'Hatsuaki' to $75.5 \%$ in 'Fuji'.

5. The total amounts of volatile compounds recovered by the high vacuum distillation method were highest in the cultivar 'Kogyoku', 9.415 ppm, followed by 'Hatsuaki' with $8.936 \mathrm{ppm}$, 'Golden Delicious' with $5.964 \mathrm{ppm}$, 'Mutsu' with 3.711 ppm and lastly 'Fuji' with $2.273 \mathrm{ppm}$.

6. From the above results it can be concluded that the cultivar 'Kogyoku' and related cultivar 'Hatsuaki' contain higher levels of volatile compounds and show a higher aroma intensity than other cultivars.
\end{abstract}

\section{Introduction}

Numerous investigations have been carried about the composition of the volatile compounds of apples, since the flavour of apples

1 Received for publication December 26, 1985. is a very important quality determination factor $(1 \sim 7,9 \sim 11,17)$. Power and Chesnut $(13,14)$ reported for the first time that the aroma constituents of several varieties of apples consisted mainly of pentyl esters of formic, acetic and hexanoic acids, a considerable portion of acetaldehyde, geraniol and 
traces of methyl and ethyl alcohol.

Flath et al. (2) studied the volatile compounds of 'Delicious' apples, and pointed out that ethyl 2-methylbutyrate, hexanal and 2hexanal were essential to the apple aroma. Katayama et al. (7) observed the presence of 15 compounds of esters and alcohols, and also Yajima et al. (18) identified sixty-seven compounds of hydrocarbons, alcohols, aldehydes, ketones, esters and miscellaneous compounds from the 'Kogyoku' ('Jonathan') apple juice and peels.

However the content and composition of the volatile compounds obtained from apple fruit differ markedly from study to study depending on the methods of determination and apple cultivars employed. To our knowledge, reports on differences of flavour in cultivars are not available except for the report stating that 'Kogyoku' shows a high intensity of aroma and is suitable for juice making(7).

The present study was undertaken to analyse the differences in the composition and content of the flavour compounds of five main cultivars in Japan and to obtain the suitability of the cultivars for processing along with establishing an index for breeding pro grams relating to flavour.

\section{Materials}

\section{Materials and Methods}

Apples of five cultivars 'Hatsuaki' (picking date Sept. 26 th), 'Kogyoku' (Oct. 17 th), 'Golden Delicious' (Oct.27 th), 'Mutsu' (Oct. 31 st), 'Fuji' (Nov. 5 th) were harvested in the orchard of the Morioka Branch of the National Fruit Tree Research Station in Mo-

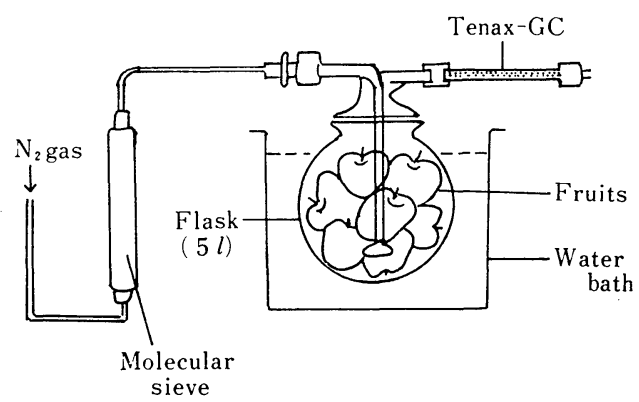

Fig. 1. Apparatus for collecting volatile compounds from apple fruits by applying the head space method. rioka Prefecture in 1983 and examined within 10 days after picking when considered ready for marketing.

\section{Determination of volatile compounds}

Volatile compounds were isolated by a modification of the head space method(5) and high vacuum distillation method(7) developed previously by Jennings and Katayama et al. respectively.

Head space method: Seven to 9 fruits $(1.72 \sim 2.8 \mathrm{~kg})$ were placed in the apparatus illustrated in Figure 1 and kept at $20^{\circ} \mathrm{C}$ by using a water bath controlled by a ther mostat. Nitrogen gas $(50 \sim 60 \mathrm{ml} / \mathrm{min})$ which passed through a molecular sieve was blown over the apples for 24 hours. The volatile compounds in the emerging gas stream were absorbed by two grams of Tenax-GC.

The volatile compounds trapped on the Tenax-GC were dissolved in ethyl ether. After the evaporation of ethyl ether by bubbling in purified nitrogen gas, the residual volatile compounds were dissolved in $10 \mu \mathrm{l}$ of $n$-hexane containing $10 \%$ butyl benzene as an internal standard, and part of this solution was injected into a gas chroma tograph.

High vacuum distillation method: A modification of the method developed previously by Katayama et al. (7) was applied in this experiment. Seven or 9 apples were used for analysis. Each fruit was cut into quar ters and cored to give $2 \mathrm{~kg}$ or more of fruit flesh. Two kg of the flesh were homogenized with $400 \mathrm{ml}$ water containing $20 \mathrm{~g}$ of $\mathrm{NaCl}$ under cooled conditions to inhibit enzymatic activity $(5,15)$.

All of the homogenate was poured into a $5 l$ flask illustrated in Figure 2. The flask was connected to a set of four cold traps at the end of which stood a vacuum pump. The volatile compounds were distilled off under the reduced pressure of $0.1 \sim 0.2 \mathrm{~mm}$ $\mathrm{Hg}$ by bubbling the purified nitrogen gas at the temperature of $35^{\circ} \mathrm{C}$ for 6 hours.

Evaporated volatile compounds under reduced pressure were caught by sequential trapping in cooled ethyl alcohol, dry ice and dry ice-acetone. Cold trap condensate con 


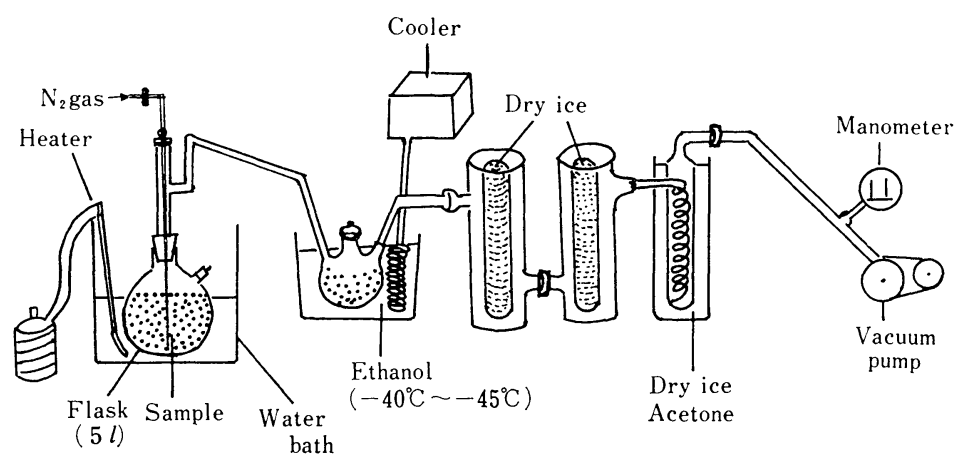

Fig. 2. Apparatus for collecting volatile from apple juice by applying the high vacuum distillation method.

taining water was collected together, the apparatus was rinsed with $100 \mathrm{ml}$ of ethyl ether and the two solutions were mixed. The mixed solution was salted out by $200 \mathrm{~g}$ of $\mathrm{NaCl}$, and the water phase washed three times with ethyl ether $(200 \mathrm{ml})$. This solution was added to the original ether solution to obtain $300 \mathrm{ml}$ of extracting solution for the volatile compounds.

The ethyl ether solution was dehydrated by $30 \mathrm{~g}$ of magnesium sulfate. After filtration of this solution, ethyl ether was evaporated by a rotary evaporator at a low temperature to obtain the volatile compounds as a residue. The residue was dissolved into $300 \mu$ of $n$-hexane containing butyl benzene as internal standard and analysed by gaschromatography.

Butyl benzene was selected as the internal standard since its retention time coincided with an uncrowded region of the apple flavour chromatogram and since it was not a constituent of apple juice.

Gas chromatography and gas chromatography-mass spectrometry

Gas chromatographic data were obtained using a Shimadzu GC-9 A gas chromatograph fitted with a flame ionization detector and using $50 \mathrm{~m} \times 0.25 \mathrm{~mm}$ fused silica capillary columns coated with FFAP (WCOT, Gaschro Ind.). The instrument was operated at a nitrogen flow of $0.8 \mathrm{ml} / \mathrm{min}$ and the column oven temperature of $70^{\circ}$ to $200^{\circ} \mathrm{C}$ was pro grammed at a rate of $3^{\circ} \mathrm{C} / \mathrm{min}$ with a sample size of $0.1 \mu 1$.

A Hewlett Packard 5992 B GC-MS system scanning at $70 \mathrm{ev}$ was used to record mass spectra data. The columns were similar to those used for analytical gas chromatography. After an initial isothermal period of $3 \mathrm{~min}$ the columns were programmed from $100^{\circ}$ to $200^{\circ} \mathrm{C}$ at a rate of increase of $5^{\circ} \mathrm{C} / \mathrm{min}$. Volatile compounds were indicated in $\mathrm{ppm}$ of the fresh weight.

Authentic samples were obtained for all the compounds detected in the apple volatile substances and identified by retention time and mass spectral analysis. Retention times of these compounds were determined under the gas chromatographic condition described above to identify the volatile compounds of apple fruit samples.

\section{Results and Discussion}

Volatile compounds identified by the application of the head space method

A typical gas chromatographic pattern of the volatile compounds of 'Kogyoku' fruits obtained by the head space method is illustrated in Figure 3. Seventy to 80 compounds were detected in the gas chromatogram peaks of which 39 compounds were identified by gas chromatography-mass spectrometry. The classes of compounds identified included 27 kinds of esters, 6 of alcohols, 2 of aldehydes, 2 of hydrocarbons, a phenol and an acid.

In these classes of compounds, the most abundant volatile constituents consisted of esters. Alcohols, aldehydes, hydrocarbons, phenol and acid were minor compounds in quantity. Of the volatile compounds detect 


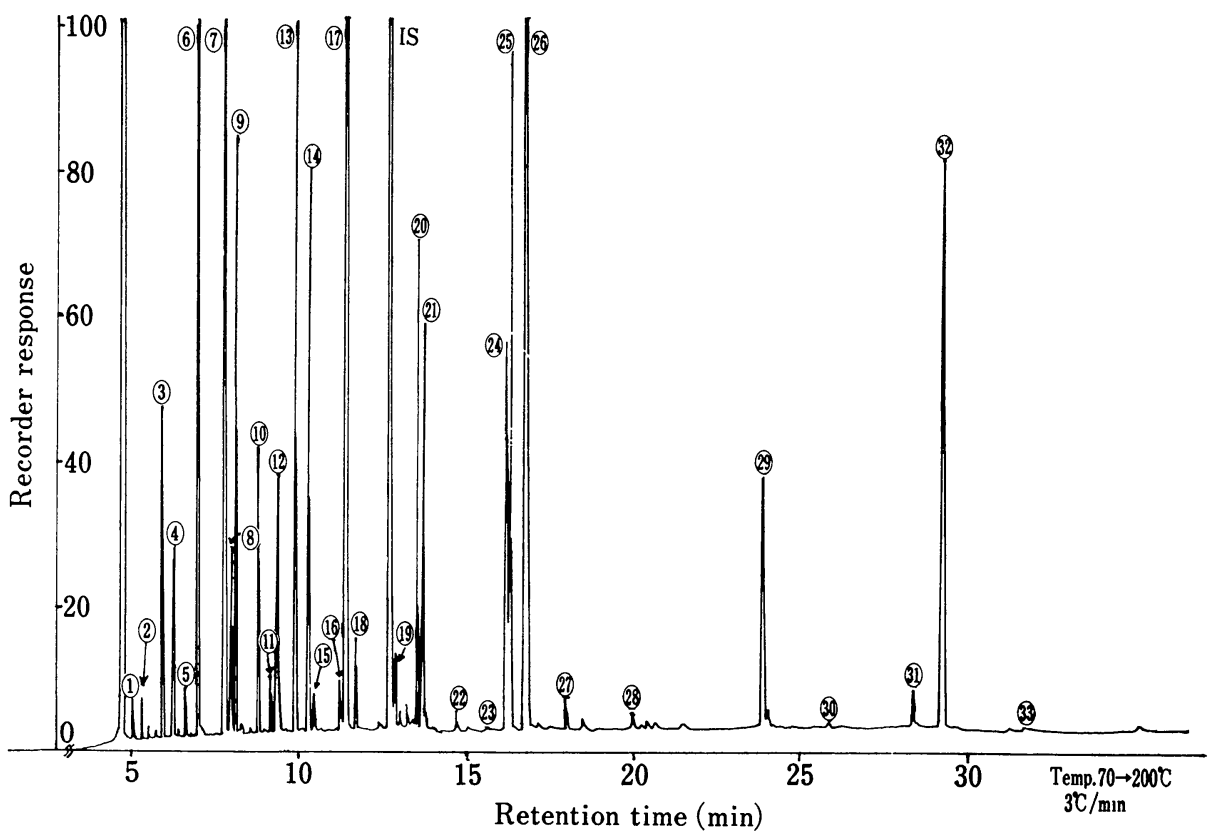

Fig. 3. Chromatorgam of head space volatile concentrate from 'Kogyoku' apple.

Peak Compound

1. Methyl acetate

2. Ethyl acetate

3. Propyl acetate

4. Isobropyl acetate

5. Ethyl 2-methyl butyrate

6. Butyl acetate

7. 2-Methyl butyl acetate

8. Butyl alcohol

9. Butyl propionate

10. Amyl acetate

11. 2-Met. but. propionate

IS=Internal standard (Butyl benzene)
12. 2-Met. but. alcohol

13. Butyl butyrate

14. Butyl 2-methyl butyrate

15. Amyl alcohol

16. 2-Met. but. butyrate

17. Hexyl acetate

18. 2-Methyl butyl 2-met. But.

19. Propyl caproate

20. Hexyl propionate

21. Hexyl alcohol

22. Isobutyl caproate
23. trans-2-hexenyl alcohol

24. Butyl caproate

25. Hexyl butyrate

26. Hexyl 2-methyl butyrate

27. 2-Methyl butyl caproate

28. Amyl caproate

29. Hexyl caproate

30. Methyl chavicol

31. trans, cis- $\alpha-$ Farnesene

32. trans, trans $-\alpha-$ Farnesene

33. Hexyl caprylate ed and identified in the cultivars used, butyl acetate, 2-methylbutyl acetate, hexyl acetate, hexyl propionate, hexyl butyrate and hexyl 2-methylbutyrate were found to be the major constituents accounting for the quantity.

Compared with the results previously obtained $(1 \sim 3,7,12,15)$, the present data were in agreement in the case of the esters of methyl acetate, ethyl acetate, propyl acetate, butyl acetate, hexyl acetate, butyl propionate, hexyl propionate, ethyl butyrate, butyl butyrate, ethyl 2-methylbutyrate and also the alcohols comprising isobutyl alcohol, butyl alcohol, 2-methylbutyl alcohol, hexyl alcohol, trans-2-hexenyl alcohol. But, 4-methoxyallybenzene which contributes to the spice like characteristic of the aroma(17) was not detected in this experiment.

Some characteristic features of the individ ual cultivars in relation to the composition and content of the volatile compounds are shown in Table 1 . Higher concentration of methyl chavicol of the phenolic compound was a characteristic of the cultivar 'Hatsuaki'. Cultivars 'Hatsuaki' and 'Kogyoku contained larger quantities of esters, with comparatively higher amounts of alcohols.

The cultivar 'Mutsu' contained esters, namely ethyl butyrate and ethyl 2-methylbutyrate. While many of the compounds may contribute to the apple-like aroma, it can be considered that ethyl 2-methylbutyrate is responsible for the special aroma of 
Table 1. Content of volatile compounds of apple fruits in relation to cultivars (head space method).

\begin{tabular}{|c|c|c|c|c|c|}
\hline & Hatsuaki & Kogyoku & $\begin{array}{l}\text { Golden. } \\
\text { Delicious }\end{array}$ & Mutsu & Fuji \\
\hline \multicolumn{6}{|l|}{ Esters } \\
\hline Methyl acetate & 0.001 & + & + & + & + \\
\hline Ethyl acetate & + & + & + & 0.005 & + \\
\hline Propyl acetate & 0.002 & 0.012 & 0.001 & + & + \\
\hline Isobutyl acetate & 0.003 & 0.008 & 0.002 & 0.001 & + \\
\hline Butyl acetate & 0.140 & 0.242 & 0.086 & 0.034 & 0.005 \\
\hline 2-Methylbutyl acetate & 0.182 & 0.300 & 0.016 & 0.008 & 0.011 \\
\hline Amyl acetate & 0.015 & 0.013 & 0.003 & 0.002 & 0.001 \\
\hline Hexyl acetate & 0.532 & 0.443 & 0.036 & 0.028 & 0.003 \\
\hline Butyl propionate & 0.040 & 0.027 & 0.004 & 0.002 & 0.002 \\
\hline 2-Methylbutyl propionate & 0.005 & 0.003 & $\operatorname{tr}$ & $\operatorname{tr}$ & $\operatorname{tr}$ \\
\hline Hexyl propionate & 0.183 & 0.028 & 0.002 & 0.002 & 0.001 \\
\hline Ethyl butyrate & $\operatorname{tr}$ & $\operatorname{tr}$ & + & 0.018 & 0.001 \\
\hline Butyl butyrate & 0.033 & 0.037 & 0.007 & 0.005 & 0.001 \\
\hline 2-Methylbutyl butyrate & 0.002 & 0.003 & $\operatorname{tr}$ & $\operatorname{tr}$ & + \\
\hline Hexyl butyrate & 0.166 & 0.041 & 0.006 & 0.008 & 0.001 \\
\hline Ethyl 2-methylbutyrate & $\operatorname{tr}$ & $\operatorname{tr}$ & $\operatorname{tr}$ & 0.003 & + \\
\hline Butyl 2-methylbutyrate & $(0.031)$ & $(0.029)$ & $(0.004)$ & $(0.005)$ & $(0.002)$ \\
\hline 2-Methylbutyl 2-methylbutyrate & 0.003 & 0.005 & $\operatorname{tr}$ & + & 0.001 \\
\hline Hexyl 2-methylbutyrate & 0.254 & 0.157 & 0.006 & 0.014 & 0.007 \\
\hline Ethyl caproate & $(0.031)$ & $(0.029)$ & $(0.004)$ & $(0.005)$ & $(0.002)$ \\
\hline Propyl caproate & + & + & $\operatorname{tr}$ & + & $\operatorname{tr}$ \\
\hline Isobuty caproate & + & + & $\operatorname{tr}$ & $\operatorname{tr}$ & $\operatorname{tr}$ \\
\hline Butyl caproate & 0.031 & 0.027 & 0.009 & 0.011 & 0.003 \\
\hline 2-Methylbutyl caproate & 0.001 & 0.002 & $\operatorname{tr}$ & + & 0.001 \\
\hline Amyl caproate & 0.006 & 0.002 & 0.003 & + & 0.001 \\
\hline Hexyl caproate & 0.052 & 0.018 & $\operatorname{tr}$ & 0.009 & 0.002 \\
\hline Hexyl caprylate & 0.001 & + & $\operatorname{tr}$ & + & + \\
\hline \multicolumn{6}{|l|}{ Alcohols } \\
\hline Isobutyl alcohol & + & + & $\operatorname{tr}$ & $\operatorname{tr}$ & $\operatorname{tr}$ \\
\hline Butyl alcohol & 0.003 & 0.011 & 0.002 & 0.002 & 0.001 \\
\hline 2-Methylbutyl alcohol & 0.004 & 0.017 & + & + & 0.001 \\
\hline Amyl alcohol & 0.003 & 0.001 & + & $\operatorname{tr}$ & + \\
\hline Hexyl alcohol & 0.017 & 0.030 & + & 0.001 & 0.001 \\
\hline trans-2-Hexenyl alcohol & 0.001 & + & + & + & + \\
\hline \multicolumn{6}{|l|}{ Aldehydes } \\
\hline Hexyl aldehyde & $\operatorname{tr}$ & $\operatorname{tr}$ & $\operatorname{tr}$ & $\operatorname{tr}$ & $\operatorname{tr}$ \\
\hline trans-2-Hexenyl aldehyde & $\operatorname{tr}$ & $\operatorname{tr}$ & $\operatorname{tr}$ & $\operatorname{tr}$ & $\operatorname{tr}$ \\
\hline \multicolumn{6}{|l|}{ Hydrocarbons } \\
\hline trans, cis- $\alpha-$ Farnesene & 0.008 & 0.003 & + & 0.002 & 0.001 \\
\hline trans, trans- $\alpha$-Farnesene & 0.114 & 0.043 & 0.005 & 0.022 & 0.006 \\
\hline \multicolumn{6}{|l|}{ Phenol } \\
\hline Methyl chavicol & 0.025 & + & + & + & + \\
\hline \multicolumn{6}{|l|}{ Acid } \\
\hline 2-Methylbutyric acid & $\operatorname{tr}$ & $\operatorname{tr}$ & $\operatorname{tr}$ & $\operatorname{tr}$ & $\operatorname{tr}$ \\
\hline Total (ppm) & 1.889 & 1.531 & 0.196 & 0.187 & 0.055 \\
\hline
\end{tabular}

+ : Below $0.001 \mathrm{ppm}$ ( ) : Double peaks which shared equal amount of volatiles

tr : trace 
apples as shown by Flath et al. (2) in 'Delicious' apples.

The parents of the cultivar 'Hatsuaki' are 'Kogyoku' and 'Golden Delicious' apples. The production of volatile compounds by 'Hatsuaki' more nearly resembles that of 'Kogyoku' as shown in Figure 4, with the exception of the content of methyl chavicol. Also these two cultivars gave a similar or-

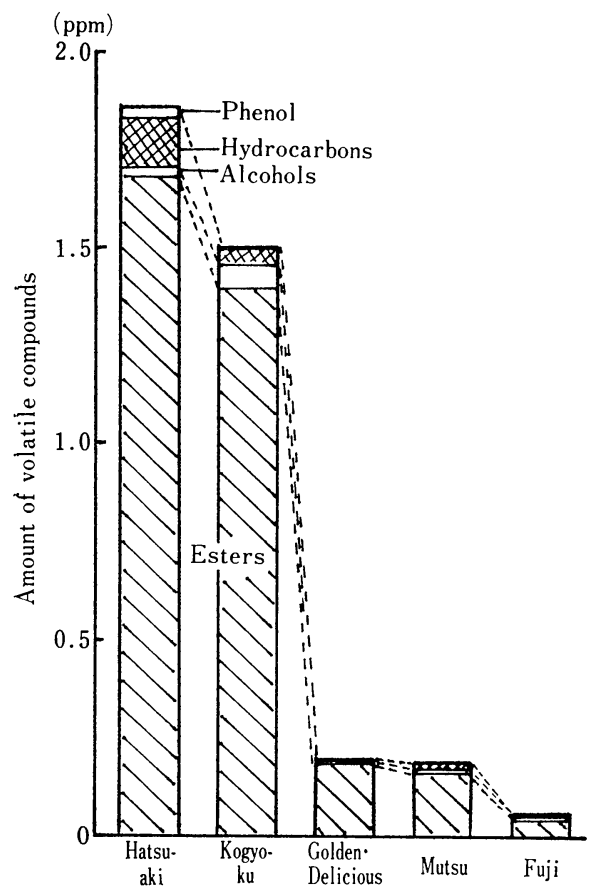

Fig. 4. Cultivar difference in cach class of volatile compounds estimated by the head space method.

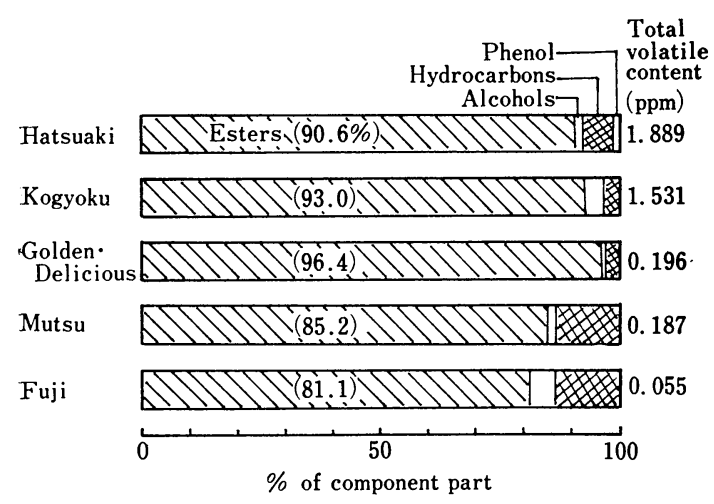

Fig. 5. Percentage of component part of each class of volatile compounds estimated by the head space method. ganoleptic evaluation with a high aroma intensity. The volatile compounds of the cultivar 'Mutsu' also resemble those of their parental cultivar, 'Golden Delicious'. Study of the volatile compounds in a known percentage may provide criteria for evaluating breeding lines and programs for the improve ment of flavour in cultivars.

Cultivar differences in the percentage of component part of volatile compounds estimated by the head space method are also illustrated in Figure 5 . The high percentage of esters recovered by this method which ranged from $81.8 \%$ ('Fuji') to $96.4 \%$ ('Golden Delicious') (as indicated in Figure 5) may indicate the ability of esterification in the fruits themselves, since the volatile compounds emanated from fresh whole fruit.

As mentioned above, esters are the most abundant volatile compounds especially in the cultivars 'Hatsuaki' and 'Kogyoku'. Schreier et al. (16) classified the apple cultivars with volatile compounds into the ester type and the alcohol type of apples. Results obtained in the cultivar 'Kogyoku' ('Janathan') and related cultivar 'Hatsuaki' agreed with the report of Schreier who that stated these cultivars belong to the ester type.

As shown in Table 1 and Figure 4, the total content of volatile compounds was the highest in 'Hatsuaki' (1.889 ppm), followed in descending order by 'Kyogyoku' (1.531 ppm), 'Golden Delicious' (0.196 ppm), 'Mutsu' (0.187 ppm) and 'Fuji' (0.055 ppm). The cultivar 'Hatsuaki' contained 35 times the amount of volatile compounds of ' $\mathrm{Fuji}$ ' which was the lowest among the cultivars examined.

Brown et al. (1) reported that many volatile substances reached maximum levels at a time which nearly coincides with the respiratory climacteric. Although the respiration climacteric was not estimated in the present materials, it can be concluded that individual amounts of volatile substances reflect the cultivar differences as the fruits were used 10 days after the optimum picking time for every cultivars.

Cultivar differences of volatile compounds shown in Figure 4, suggested that the 
Table 2. Content of volatile compounds of apple fruit juice in relation to cultivars (high vacuum distillation method).

\begin{tabular}{|c|c|c|c|c|c|}
\hline & Hatsuaki & Kogyoku & $\begin{array}{l}\text { Golden. } \\
\text { Delicious }\end{array}$ & Mutsu & Fuji \\
\hline \multicolumn{6}{|l|}{ Esters } \\
\hline Methyl acetate & + & + & + & + & + \\
\hline Ethyl acetate & 0.027 & 0.022 & 0.011 & 0.011 & 0.010 \\
\hline Propyl acetate & + & + & + & $\operatorname{tr}$ & $\operatorname{tr}$ \\
\hline Isobutyl acetate & + & + & + & + & + \\
\hline Butyl acetate & 0.839 & 0.417 & 0.562 & 0.106 & 0.023 \\
\hline 2-Methylbutyl acetate & 0.450 & 0.472 & 0.190 & 0.048 & 0.135 \\
\hline Amyl acetate & 0.042 & 0.016 & 0.027 & + & + \\
\hline Hexyl acetate & 1.376 & 0.478 & 0.684 & 0.178 & 0.043 \\
\hline Butyl propionate & 0.026 & 0.026 & 0.026 & + & + \\
\hline 2-Methylbutyl propionate & $\operatorname{tr}$ & $\operatorname{tr}$ & $\operatorname{tr}$ & $\operatorname{tr}$ & $\operatorname{tr}$ \\
\hline Hexyl propionate & 0.023 & + & 0.009 & $\operatorname{tr}$ & $\operatorname{tr}$ \\
\hline Ethyl butyrate & $\operatorname{tr}$ & $\operatorname{tr}$ & $\operatorname{tr}$ & 0.064 & + \\
\hline Butyl butyrate & $\operatorname{tr}$ & $\operatorname{tr}$ & $\operatorname{tr}$ & $\operatorname{tr}$ & $\operatorname{tr}$ \\
\hline 2-Methylbutyl butyrate & $\operatorname{tr}$ & $\operatorname{tr}$ & $\operatorname{tr}$ & $\operatorname{tr}$ & $\operatorname{tr}$ \\
\hline Hexyl butyrate & 0.057 & 0.021 & 0.067 & 0.034 & $\operatorname{tr}$ \\
\hline Ethyl 2-methylbutyrate & $\operatorname{tr}$ & $\operatorname{tr}$ & $\operatorname{tr}$ & 0.014 & + \\
\hline Butyl 2-methylbutyrate & $(+)$ & $(+)$ & $(0.030)$ & $(0.043)$ & $(0.001)$ \\
\hline 2-Methylbutyl 2-methylbutrate & $\operatorname{tr}$ & $\operatorname{tr}$ & $\operatorname{tr}$ & $\operatorname{tr}$ & $\operatorname{tr}$ \\
\hline Hexyl 2-methylbutyrate & 0.074 & 0.053 & 0.049 & 0.053 & 0.029 \\
\hline Ethyl caproate & $(+)$ & $(+)$ & $(0.030)$ & $(0.043)$ & $(0.001)$ \\
\hline Propyl caproate & + & $\operatorname{tr}$ & $\operatorname{tr}$ & $\operatorname{tr}$ & $\operatorname{tr}$ \\
\hline Isobutyl caproate & + & 0.016 & 0.009 & $\operatorname{tr}$ & $\operatorname{tr}$ \\
\hline Butyl caproate & 0.013 & 0.015 & 0.038 & 0.024 & 0.011 \\
\hline 2-Methylbutyl caproate & $\operatorname{tr}$ & $\operatorname{tr}$ & $\operatorname{tr}$ & $\operatorname{tr}$ & $\operatorname{tr}$ \\
\hline Amyl caproate & $\operatorname{tr}$ & $\operatorname{tr}$ & $\operatorname{tr}$ & $\operatorname{tr}$ & $\operatorname{tr}$ \\
\hline Hexyl caproate & 0.024 & $\operatorname{tr}$ & 0.019 & 0.026 & $\operatorname{tr}$ \\
\hline Hexyl caprylate & $\operatorname{tr}$ & $\operatorname{tr}$ & $\operatorname{tr}$ & $\operatorname{tr}$ & $\operatorname{tr}$ \\
\hline \multicolumn{6}{|l|}{ Alcohols } \\
\hline Isobutyl alcohol & 0.067 & 0.135 & 0.017 & 0.022 & 0.011 \\
\hline Butyl alcohol & 2. 367 & 2.688 & 1.248 & 0.824 & 0.265 \\
\hline 2-Methylbutyl alcohol & 0.458 & 1.501 & 0.095 & 0.169 & 0.408 \\
\hline Amyl alcohol & 0.032 & 0.031 & 0.017 & 0.022 & 0.013 \\
\hline Hexyl alcohol & 1.653 & 1.804 & 1.323 & 1.220 & 0.598 \\
\hline trans-2-Hexenyl alcohol & 0.188 & 0.403 & 0.166 & 0.298 & 0.426 \\
\hline \multicolumn{6}{|l|}{ Aldehydes } \\
\hline Hexyl aldehyde & 0.320 & 0.141 & 0.356 & 0.088 & 0.028 \\
\hline trans-2-Hexenyl aldehyde & 0.846 & 0.894 & 0.913 & 0.388 & 0.258 \\
\hline \multicolumn{6}{|l|}{ Hydrocarbons } \\
\hline trans, cis- $\alpha$-Farnesene & $\operatorname{tr}$ & $\operatorname{tr}$ & $\operatorname{tr}$ & $\operatorname{tr}$ & $\operatorname{tr}$ \\
\hline trans, trans- $\alpha-$ Farnesene & 0.020 & 0.024 & 0.049 & 0.036 & 0.013 \\
\hline \multicolumn{6}{|l|}{ Phenol } \\
\hline Methyl chavicol & $\operatorname{tr}$ & $\operatorname{tr}$ & $\operatorname{tr}$ & $\operatorname{tr}$ & $\operatorname{tr}$ \\
\hline \multicolumn{6}{|l|}{ Acid } \\
\hline 2-Methylbutyric acid & 0.034 & 0.258 & 0.029 & + & + \\
\hline Total (ppm) & 8.936 & 9.415 & 5.964 & 3.711 & 2.273 \\
\hline
\end{tabular}

$+:$ Below $0.001 \mathrm{ppm} \quad$ ( ) : Double peaks which shared equal amount of volatiles tr : trace 


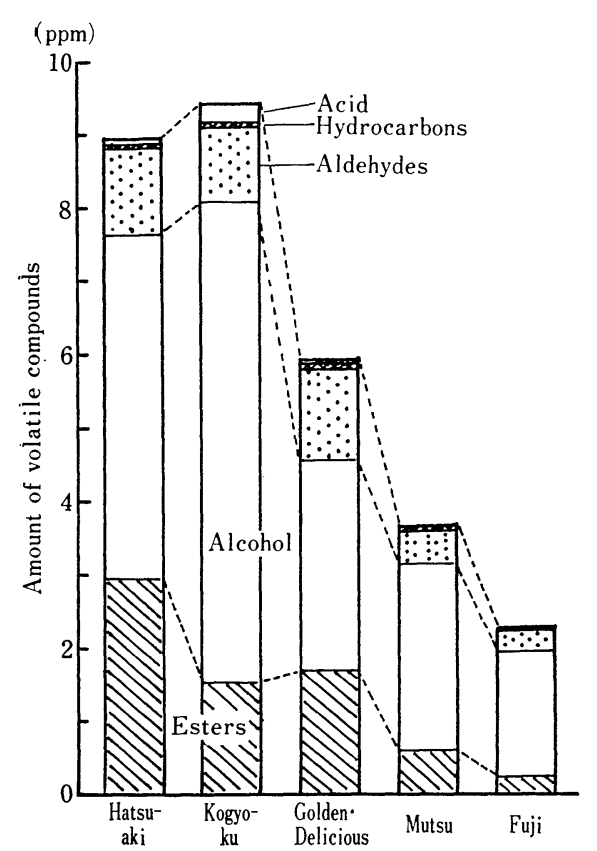

Fig. 6. Cultivar differences in each class of volatile compounds estimated by the high vacuum distillation method.

'Hatsuaki' and 'Kogyoku' have a high ability of emanation of volatile compounds from the whole fruit. In taking into account the organoleptic evaluation of apple flavour in relation to the method of recovery, the head space method may be more suitable for the estimation of flavour intensity by olfactory tests.

Volatile compounds identified by the application of the high vacuum distillation method

Table 2 shows the amounts of volatile compounds detected from the fruit homogenate of the respective cultivars by the high vacuum distillation and gas chromatographic method.

Few differences were observed in the composition and content of the volatile compounds detected by the high vacuum distillation method compared to the head space method. Esters of hexyl acetate, butyl acetate, 2-methylbutyl acetate and alcohols comprising butyl alcohol, hexyl alcohol were the major components estimated by the high vaccum distillation method. In contrast, the total amount of volatile compounds recovered by the high vacuum distillation method for

\begin{tabular}{|c|c|c|c|c|}
\hline \multirow[b]{2}{*}{ Hatsuaki } & & \multicolumn{2}{|c|}{$\begin{array}{l}\text { Acid- } \\
\text { Hydrocarbons } \\
\text { Aldehydes }\end{array}$} & \multirow{2}{*}{$\begin{array}{l}\text { Total } \\
\text { volatile } \\
\text { content } \\
\text { (ppm) } \\
8.936\end{array}$} \\
\hline & Esters $(33.0 \%)$ y & Alcohols $(53.3 \%)$ & $(13,0)$ & \\
\hline Kogyoku & $(16.3) y$ & (69.7) & (ii.0) & 9.415 \\
\hline $\begin{array}{l}\text { Golden } \\
\text { Deliciou }\end{array}$ & $\Delta \backslash(29,0), y$ & $(48.3)$ & & 5.964 \\
\hline Mutsu & $(16.4)$ & $(69.7)$ & 13.0 & 3.771 \\
\hline Fuji & $(11.4)$ & $(75.5)$ & $(12.5$ & 2.273 \\
\hline & $\%$ & mponent part & & 00 \\
\hline
\end{tabular}

Fig. 7. Percentage of component part of each class of volatile compounds estimated by the high vacuum distillation method.

6 hours was higher than that of the volatile compounds collected for 24 hours by the head space method.

Figures 6 and 7 indicate the total contents of volatile compounds or percentage of individual classes of esters, alcohols, aldehydes, hydrocarbons, phenol and acid, respectively. It was recognized that the class of alcohols was the most abundant (Figure 6) showing a percentage ranging from $53.3 \%$ in 'Hatsuaki' to $75.5 \%$ in 'Fuji' (Figure 7). On the other hand, the percentage of esters which accounted for $80 \%$ or more of the total content in the case of the head space method was very low ranging from $11.4 \%$ in ' $\mathrm{Fuji}$ ' to $33.3 \%$ in 'Hatsuaki' when the high vaccum distillation method was applied. In the other classes of volatile compounds, the concentrations were very low except for the aldehydes which showed a relatively high content compared to that detected by the head space method.

The reason why the content of the esters is low in the high vacuum distillation method may be ascribed to the fact that the esters did not evolve continuously, since the fruit was crushed and lost the ability of esterification as in the case of controlled atmosphere storage(8). The total amounts of volatile compounds recovered by the high vacuum distillation method were highest in the cultivar 'Kogyoku', 9. $415 \mathrm{ppm}$ (Table 2) followed by 'Hatsuaki' $8.936 \mathrm{ppm}$, 'Golden Delicious' $5.964 \mathrm{ppm}$, 'Mutsu' $3.711 \mathrm{ppm}$ and lastly 'Fu 
ji' 2. $273 \mathrm{ppm}$. This pattern of volatile content was found to be in agreement with the organoleptic tests of the cultivars used.

It has been shown that the cultivars 'Kogyoku' and 'Hatsuaki' both of which contain high levels of volatile compounds may be used for the improvement of the flavour in fruit processing and breeding programs.

\section{Literature cited}

1. BROWN, D. S., J. R. BUCHANAN and J. R. HICKS. 1966. Volatiles from apple fruits as related to variety, maturity and ripeness. Proc. Amer. Soc. Hort. Sci. 88 : 98-104.

2. Flath, R. A., D. R. BLACK, D. G. GUADAGNI, W. H. MEFADDEN and T. H. SCHULTZ. 1967. Indentification and organoleptic evaluation of compounds in Delicious apple. J. Agric. Food Chem. $15: 29-35$.

3. Flath, R. A., D. R. BLACK, R. R. FORREY, G. M. MCDONALD, T. R. MON and R. TERANISHI.

1969. Volatiles in gravenstein apple essence identified by gas chromatography-mass spectrometry. J. Chromatogr. Sci. $7: 508-512$.

4. Grevers, G. and J. J. DOESBURG. 1965. Volatiles of apples during strage and ripening. J. Food Sci. $30: 412-415$.

5. JENNINGS, W. G. 1965. Influence of temperature and salt addends on vapor equilibration of headspace. J. Food Sci. $30: 445-449$.

6. JENNINGS, W. G., R. WOHLEB and M. J. LEWIS. 1972. Gas chromatographic analysis of headspace volatiles of alcoholic beverages. J. Food Sci. $37: 69-71$.

7. Katayama, O., A. Watanabe and I. Yamato. 1966. The aroma components in fruits and vegetables, part I. Apple volatiles. J. Japan Soc. Food. Sci. Technol. $13: 416-419$ (in Japanese).

8. LidSTER, P. D., H. J. LightFoOT and K. B.
MCRAE. 1983. Production and regeneration of principal volatiles in apples stored in modiffied atmosphere and air. J. Food Sci. $48: 400-402,410$.

9. MaCGregor, D. R., H. Sugisawa and J.S. MATHEWS. 1964. Apple juice volatiles. J. Food Sci. $29: 448-455$.

10. Nishimura, K. and Y. Hirose. 1964. The aroma constituents of 'Kogyoku' apples. Agric. Biol. Chem. $28: 1-4$.

11. OISHI, S. 1976. Volatiles from apples as related to variety. Kaseigaku Zasshi $27: 566-$ 568 (in Japanese).

12. Panasiuk, O., F. B. TAlley and G. M. Sapers. 1980. Correlation between aroma and volatile composition of McIntosh apples. J. Food Sci. 45 : 989-991.

13. POWER, F. B. and V. K. ChEsnut. 1920. The odorous constituents of apples. Estimation of acetaldehyde from the ripe fruit. J. Amer. Chem. Soc. $42: 1509-1525$.

14. POWER, F. B. and V. K. Chesnut. 1922. The odorous constituents of apples. II. Evidence of the presence of geraniol. J. Amer. Chem. Soc. 44 : 2938-2942.

15. SAPERS, G. M. 1977. Volatile composition of McIntosh apple juice as a function of maturity snd ripeness indices. J. Food Sci. 42 : $44-47$.

16. SCHREIER, P., F. DRAWERT and M. SCHMID. 1978. Changes in the composition of neutral volatile components during the production of apple brandy. J. Sci. Food Agric. 29 : 728-736.

17. Williams, A. A., O.G. Tucknott and M. J. LEWIS. 1977. 4-Methoxyallylbenzene: an important aroma component of apples. J. Sci. Food Agric. $28: 185-190$.

18. YAJIMA, I., T. YANAI, M. NAKAMURA, H. SAKAKIBARA and K. HAYASHI. 1984. Volatile flavor components of 'Kogyoku' apples. Agric. Biol. Chem. $48: 849-855$. 
リンゴ果実の香気成分の検索と品種特性

垣内典夫・森口早苗

農林水産省果樹試験場 305 茨城県筑波郡谷田部町

福田博之

農林水産省果樹試験場盛岡支場 $020-01$ 盛岡市下欴川

市村信友・加藤 豊・馬場良明

曽田香料株式会社研究所 270-02 千葉県野田市

\begin{abstract}
摘 要
リンゴの香気にかかわる品種の育成や利用加工上の指 針を確立するため, 主要リンゴ 5 品種の生鮮果実の香気 成分の検索と品種特性について, 丸ごと果実のへッドス ペース法と破哗果実 (生鮮果汁) の高真空蒸留法により 香気成分を回収して検討した。

1. ヘッドスペース法による香気の回収結果から，70 〜80の成分がガスクロパターンとして検出され，そのう ち39成分をガスクロマトグラフ及びガスクロマトグラ フ・質量分析計により同定した.

2. 同定された 39 成分の内訳は, エステル類 27, アル コール類 6 , アルデヒド類 2 , 炭化水素類 2 , フェノー ル類 1 及び酸類成分であった。

3. ヘッドスペース法による全香気成分のうち，エス テル類は全品種とも $80 \%$ 以上を占めた。また，全香気成

‘ゴールデン・デリシャス’ (0.196). ‘陸奥’ (0.187)> ‘ふじ’(0.055) の順であった.

4. 高真空蒸留法に基づく香気成分組成もへッドスペ 一ス法によるそれとほとんど同様であった。しかし，高 真空蒸留法による香気成分組成はアルコール類が最も多 く、 ‘はつあき’の $53.3 \%$ ‘らじ’ の75.5\%に及んだ.

5. 高真空蒸留法による 全香気成分の 回収量は, “紅 玉’ (9.415 ppm)>“はつあき’ (8. 936)>‘ゴールデン・ デリシャス’ (5. 964)>“陸奥’ (3.711)> ‘ふじ’ (2.273) の順であった.

6. 以上の結果から，“紅玉” やその血縁の ‘はつあき” 種の香気成分は，香気の回収方法を問わず，他の 3 品種 より著しく多く, 香り立ちの良い原因であることが判明 した.
\end{abstract} 分含有量は ‘はつあき' (1.889 p pm)>“紅玉' (1.531)> 